\title{
Characteristics of direct transesterification using ultrasound on oil extracted from spent coffee grounds
}

\author{
Yeong Su Kim ${ }^{1}$, Duk Gam $\mathrm{Woo}^{2^{\dagger}}$, Tae Han $\mathrm{Kim}^{1^{\dagger}}$ \\ ${ }^{1}$ Department of Bio-industrial Machinery Engineering, Kyungpook National University, Daegu, 41566, Korea \\ ${ }^{2}$ Research Faculty of Agriculture, Hokkaido University, Sapporo, 060 - 8589, Japan
}

\begin{abstract}
Spent coffee grounds (SCG), the residue after brewing coffee beverage, is a promising biodiesel feedstock due to its high oil contents (15-20\%). However, SCG should be pretreated to reduce the high free fatty acid content, which hampers transesterification reaction. To overcome this, we explored a direct transesterification reaction of SCG using ultrasound irradiation and identified the optimal sonication parameters. A high fatty acid methyl ester (FAME) content, up to $97.2 \%$, could be achieved with ultrasound amplitude of $99.2 \mu \mathrm{m}$, irradiation time of 10 min, and methanol to oil ratio of 7:1 in the presence of potassium hydroxide concentration of $1.25 \mathrm{wt} . \%$. In addition, we demonstrated that ultrasound irradiation is an efficient method to produce biodiesel from untreated SCG in a short time with less energy than the conventional mechanical stirring method. The physical and chemical properties of the SCG biodiesel met the requirements for an alternative fuel to the current commercial biodiesel.
\end{abstract}

Keywords: Biodiesel, Energy consumption, Pretreatment, Spent coffee grounds, Transesterification, Ultrasound

\section{Introduction}

Biodiesel (BD) produced mainly from vegetable oils is the most promising and practical alternative energy for transportation because it can be produced, distributed, and stored using the current power units and infrastructure. The use of vegetable oil is limited due to demand. Also, potential feed shortage and increase in feed price further limits its usage [1]. In this regard, research is ongoing for $\mathrm{BD}$ that can be produced from non-feed and industrial waste materials. Spent coffee grounds (SCG) are a promising and practical BD feedstock [2].

Coffee is one of the most popular beverages worldwide. In 2017, annual consumption amounted to 97 million tons, with trading volume second to that of petroleum [3,4]. Noting that $2 \mathrm{~kg}$ of SCG is produced for each $1 \mathrm{~kg}$ of coffee, Nestle, a global coffee manufacturer has been exploring various approaches to using SCG for the production of compost, solid fuel, and $\mathrm{BD}[5,6]$. The oil content of SCG is in the range of $15-20 \%$. Efficient conversion of this high oil content into BD would reduce the costs of SCGs disposal and BD production, making this promising alternative energy more economically feasible [7].

The oil extracted from SCG contains $2.01-5.02 \%$ free fatty acids

This is an Open Access article distributed under the term of the Creative Commons Attribution Non-Commercial License (http://creativecommons.org/licenses/by-nc/3.0/) which permits unrestricted non-commercial use, distribution, and reproduction in any medium, provided the original work is properly cited.

Copyright (C) 2020 Korean Society of Environmental Engineers
(FFA), which facilitates saponification and water production during the transesterification process, consequently reducing BD yield [6]. In general, efficient alkali-catalyzed transesterification reaction requires FFA content less than $1.0 \%$ [8]. According to previous study, the FFA content needs to be less than $0.5 \%$ for alkaline transesterification to occur [9]. For transesterification of low-grade oils such as SCG, waste cooking oil, and animal fat, the feedstock should be pretreated using an acid catalyst to remove FFA [10]. The pretreatment process is usually carried out at high pressure and temperature in the presence of an acid catalyst, increasing energy consumption and adding wastewater treatment cost to the BD price [11]. The cost of the pretreatment process performed to remove FFAs from low-grade raw materials increases the $\mathrm{BD}$ production cost. According to Y. Zhang et al. [12], although the higher price of virgin oils is 2.5 times higher than that of waste cooking oils, the break-even price of waste cooking oil-derived $\mathrm{BD}$ is approximately $3 \%$ higher than that of virgin oil-derived from $\mathrm{BD}$ due to the higher pretreatment cost of waste cooking oils. Therefore, a novel approach is required to reduce the cost and energy invested in the pretreatment process.

To address this issue, many recent studies have attempted to take advantage of ultrasound for SCG pretreatment [13] and activa-

Received February 27, 2019 Accepted July 01, 2019

${ }^{\dagger}$ Corresponding author

Email: dgwoo@bpe.agr.hokudai.ac.jp

Tel: +81-11-706-2539 Fax: +81-11-706-4147

ORCID: 0000-0003-0281-4342 
tion of the transesterification reaction. Ultrasound irradiation is reported to facilitate mass transfer across interface during chemical reactions by inducing cavitation [14]. Ultrasound has been used for the production of $\mathrm{BD}$ from plant oils, including soybean oil, canola oil, corn oil, sunflower oil, coconut oil [2, 14-17], and non-food feedstock, including waste cooking oil, beef tallow, and SCG [18-20].

Hingu et al. [18] investigated the potential use of ultrasound for the transesterification of waste cooking oil and examined the influence of ultrasound power, potassium hydroxide $(\mathrm{KOH})$ concentration, the molar ratio of methanol to oil, and reaction time on the FAME content of BD. The ester content could be increased up to $89.5 \%$ when the waste cooking oil was sonicated at $45^{\circ} \mathrm{C}$ for $40 \mathrm{~min}$ with ultrasound power of $200 \mathrm{~W}$, methanol to oil molar ratio of $6: 1$, and $\mathrm{KOH}$ concentration of 1.0 wt.\%. Compared to a mechanical stirring method at an equivalent condition, the ester content was $32 \%$ higher [18].

Teixeira et al. [19] used ultrasound for the transesterification of beef tallow ( $24 \mathrm{kHz}, 400 \mathrm{~W}$ ). When the transesterification was carried out with methanol to oil molar ratio of $6: 1, \mathrm{KOH}$ concentration of 0.5 wt.\%, and reaction time of $70 \mathrm{~s}$ at $45^{\circ} \mathrm{C}$, the ester conversion rate was $92 \%$, which was comparable to the $91 \%$ achieved using a mechanical stirring method. In their study, improvement in reaction time by the use of ultrasound was found: the reaction time required for equivalent conversion was reduced significantly (to $<1 \mathrm{~h}$ ) [19].

Liu et al. [21] attempted a direct conversion of SCG, instead of using the oil extracted from SCG, to BD using an in-situ BD process. They experimented with catalyst concentration, reaction time, and temperature. The highest FAME content was $95.3 \%$ in the transesterification performed at $70^{\circ} \mathrm{C}$ for $12 \mathrm{~h}$ in the presence of 20 wt.\% $\mathrm{H}_{2} \mathrm{SO}_{4}$. This FAME content is below the level specified in the EN14103 standard, and this approach suffers from a higher acid catalyst concentration and longer reaction time. The amount of acid catalyst was 20 times higher than that of the conventional acid-catalyzed transesterification (1.0-5.0 wt.\% $\mathrm{H}_{2} \mathrm{SO}_{4}$ ) [22] and required substantially longer reaction times ( $>10 \mathrm{~h}$ ) [23].

Burton et al. [24] compared the $\mathrm{BD}$ conversion rates by KOH-catalyzed transesterification and enzymatic transesterification reactions. The SCG samples were pretreated with hydrochloric acid, methanol and oil mixture (40:1 mole/mole) for $2 \mathrm{~h}$. For the $\mathrm{KOH}$-catalyzed transesterification, the conversion rate was less than $90 \%$ when the reaction was allowed at $55^{\circ} \mathrm{C}$ for $1 \mathrm{~h}$ with $1.0 \mathrm{wt} . \%$ catalyst and 6:1 of methanol to oil molar ratio. For the enzymatic transesterification, the $\mathrm{BD}$ conversion rate was increased up to $98.5 \%$ when the reaction was allowed to proceed at $35^{\circ} \mathrm{C}$ for 72 $\mathrm{h}$ with $2.0 \mathrm{~g}$ enzyme. During the transesterification reaction, a mixture of methanol to oil (3:1 mole/mole) was added. After a specified time, the same mixture, but with a different molar ratio (1:3) was added. Al-Hamamre et al. [25] achieved a BD conversion of $85.5 \%$ in one-step transesterification reaction at $65^{\circ} \mathrm{C}$ within $4 \mathrm{~h}$. The molar ratio of $\mathrm{MeOH}-\mathrm{KOH}$ to FFA was 9:1. In a two-step reaction, they first pretreated SCG with 1.0 wt.\% sulfuric acid and 10-20 $\mathrm{mL}$ methanol for $4 \mathrm{~h}$. In the following transesterification reaction, the BD conversion rate of $99 \%$ was achieved at $60^{\circ} \mathrm{C}$ within $6 \mathrm{~h}$ with a 9:1 molar ratio of $\mathrm{MeOH}$ to FFA and 1.5 wt.\% of $\mathrm{KOH}$.

Rocha et al. [20] used an ultrasonic bath ( $40 \mathrm{kHz}, 160 \mathrm{~W}$ ) for
SCG pretreatment and transesterification. The highest ester content was $97 \%$ with $\mathrm{H}_{2} \mathrm{SO}_{4} 3.5$ wt.\%, methanol to oil molar ratio of $9: 1$, and reaction time of $60 \mathrm{~min}$ at $60^{\circ} \mathrm{C}$. However, to date, the impact of the sonication parameters, such as ultrasound amplitude and irradiation time, on the transesterification of SCG oil have not been elucidated.

In this study, we identified the optimal ultrasound amplitude and irradiation time (reaction time) for efficient ultrasound-assisted transesterification, and various methanol to oil molar ratio and catalyst concentration were investigated to achieve the highest FAME content at a given sonication condition. In addition, the energy consumption and material costs for various BD production methods were estimated to analyze the economic feasibility of the ultrasound-assisted BD production Furthermore, the physical and chemical properties, including cetane number, oxidation stability, and sulfur content, of the SCG BD were determined to evaluate the feasibility as an alternative to the current commercial BD.

\section{Materials and Methods}

\subsection{Materials and Extraction Process}

The SCG used in this study was collected from retail coffee stores, and dried at $105^{\circ} \mathrm{C}$ for $24 \mathrm{~h}$ before extracting the oil. Dried SCG (2 kg) was placed in an oil press machine (BDF-200M, Shinjin Grab Industrial Co., Korea) and pressurized at $600 \mathrm{kgf} / \mathrm{cm}^{2}$ and $160^{\circ} \mathrm{C}$ for $30 \mathrm{~min}$. The expressed oil was filtered to remove impurities using a glass fiber filter. On average, $159 \mathrm{~g}$ of oil was extracted from $2 \mathrm{~kg}$ of SCG. A transesterification reaction was carried out using $50 \mathrm{~g}$ of SCG oil.

\subsection{Determination of Acid Value}

The Acid Values (AV) of extracted SCG oil and waste cooking oil were determined and compared. AV was measured according to the method described in the Korean Standard (KS H ISO 660), and FFA content was calculated using Eq. (1). SCG was pretreated to remove FFA in the mixture of methanol (25 wt.\%) and $\mathrm{H}_{2} \mathrm{SO}_{4}$ (0.5 wt.\%) at $65^{\circ} \mathrm{C}$ and $250 \mathrm{rpm}$ for $1 \mathrm{~h}$. After washing with distilled water to remove residual methanol and sulfuric acid, the treated SCG was dried before transesterification.

$$
\text { FFA }(\%)=A V \times 282 / 56.1 \times 100 / 1000
$$

\subsection{Transesterification of SCG}

The transesterification of SCG was performed using either mechanical stirring or ultrasound irradiation. In the mechanical method, the transesterification reaction was allowed to proceed for $1 \mathrm{~h}$ at $55^{\circ} \mathrm{C}$ and $250 \mathrm{rpm}$. The methanol to oil molar ratios and $\mathrm{KOH}$ concentrations were varied to identify the optimal condition (Table S1).

In ultrasound-assisted transesterification, the methanol to oil molar ratio and $\mathrm{KOH}$ concentration were fixed to 7:1 and 1.5 wt.\%, respectively, and the ultrasound amplitude and irradiation time (reaction time) were varied same as above as summarized in Table 1. Previous studies reported that the increase in reaction temperature due to ultrasound-induced cavitation evaporates methanol, resulting 
Table 1. Test Variables for Using Ultrasound to Transesterification

\begin{tabular}{lc}
\hline Contents (unit) & Variable \\
\hline Ultrasound irradiation amplitude $(\mu \mathrm{m})$ & $24.8,43.4,62.0,80.6$, \\
& $99.2,117.8$ \\
Ultrasound irradiation time $(\mathrm{min})$ & $5,10,20,30,40,50,60$ \\
\hline
\end{tabular}

in lower $\mathrm{BD}$ conversion rates at reaction temperatures higher than $55^{\circ} \mathrm{C}[26,27]$. To avoid rapid temperature increase due to continuous ultrasound irradiation, the samples were kept in a water bath at $55^{\circ} \mathrm{C}$ during the reaction.

To investigate the influence of the methanol to oil molar ratio and catalyst concentration on ultrasonic transesterification, methanol to oil molar ratio was varied from $3: 1$ to $11: 1$ and catalyst concentration from 1.0 to 2.0 wt.\% (same for mechanical transesterification). Once the reaction was completed, BD was separated from glycerol using a separation funnel. Then, BD was washed with distilled water to remove any potential residuals and heated to $110^{\circ} \mathrm{C}$ to remove moisture.

The sonication was performed using an ultrasonic processor (VCX-750, Sonics \& Materials Inc., USA, 750 W, $20 \mathrm{kHz}$ ) equipped with a solid-type horn (13-mm diameter, 139-mm length, and maximum amplitude of $124 \mu \mathrm{m}$ ). A heating stirrer (Corning PC-420D, Corning, USA) was used. Transesterification reaction was carried out using anhydrous methanol (99.8\%) in the presence of $\mathrm{KOH}$ (85\%). All transesterifications were repeated five times, and the reported results represent the averages of the five measurements.

\subsection{Energy Consumption and Input Cost for Transesterification}

An energy meter (HPM-100A, AD power, Rep. Korea) was used to measure the power consumption of the units used in the processes [28-30]. For each, the amount of energy consumed was measured five times, and the average values were used. The unit costs presented in Table S2 were used to determine the energy and material cost for $\mathrm{BD}$ production. The reaction condition that yielded the highest conversion rate was referred to in the energy and material cost analysis. The SCG cost was US\$ 0.02/kg [31], and for electric power, the industrial electricity price provided by Korea Electric Power Corporation (KEPCO) was used [32]. The unit costs of catalysts and solvents, including methanol and $\mathrm{KOH}$, were calculated based on the actual purchase price. Therefore, it should be noted that the material cost estimated in this study was higher than the industrial production cost, where the material cost can be lowered by large purchase volume [12, 33, 34].

\subsection{Analysis of SCG BD}

The FAME content produced from SCG oil was determined following the method described in the EN 14103 standard. Gas chromatography (GC 6850, Agilent Technologies, Inc., USA) equipped with FID and HP-Innowax column $(30 \mathrm{~m} \times 320 \mathrm{~mm} \times 0.25 \mu \mathrm{m})$ was used for the FAME analysis. The internal standard was prepared by adding 0.5 g methyl heptadecanoate (C17) into a volumetric flask containing $50 \mathrm{~mL}$ heptane $(10 \mathrm{mg} / \mathrm{mL})$. Helium was used as the carrier gas. The temperatures of the inlet and FID were set to 250 and $300^{\circ} \mathrm{C}$, respectively. The oven temperature was maintained at $210^{\circ} \mathrm{C}$ for $9 \mathrm{~min}$ and increased to $230^{\circ} \mathrm{C}$ at the rate of $20^{\circ} \mathrm{C} / \mathrm{min}$ and maintained for $10 \mathrm{~min}$. The injection volume was $1.0 \mu \mathrm{l}$ (80:1 split mode).

The physical and chemical properties of the SCG BD were analyzed at the Korean Petroleum Quality and Distribution Authority (K-Petro) using the test standards summarized in Table S3.

\section{Results and Discussion}

\subsection{Evaluation of Acid Value}

The AV of SCG oil was compared to that of waste cooking oil. The results before and after the pretreatment are summarized in Table S4. The AV of the untreated waste cooking oil were between 1.4 and $3.73 \mathrm{mgKOH} / \mathrm{g}$ (FFA 0.7-1.86\%) and after the pretreatment, decreased to $0.327 \mathrm{mgKOH} / \mathrm{g}$ (FFA $0.16 \%$ ).

The AV of untreated SCG oil was 6.3-8.5 mgKOH/g (FFA 3.15$4.25 \%$ ), which was higher than that of the waste cooking oil (low-grade BD feedstock) by 2.4-2.5\%p. FFA contents higher than $1.0 \%$ hampers the separation of ester from glycerin in alkali-catalyzed transesterification reaction, lowering overall ester conversion rate $[10,35]$.

\subsection{Transesterification Using Mechanical Stirring}

Fig. 1 shows the effects of methanol to oil molar ratio and catalyst concentration used in mechanical transesterification on the FAME content. When methanol to oil molar ratio was fixed to $7: 1$, the FAME content increased with the catalyst concentration up to 2.0 wt.\%. No further improvement was observed at a higher catalyst concentration. Similarly, in all other molar ratios, the FAME content peaked at specific catalyst concentrations. The maximum FAME content in mechanical transesterification was $87.8 \%$ with the methanol to oil molar ratio of 7:1 and 2.0 wt.\% catalyst concentration. At this condition, the BD yield was $56.2 \%$. The SCG BD produced by mechanical transesterification failed to meet the BD quality standard (FAME content $\geq 96.5 \%$ ). This result could be ascribed to the high FFA content of untreated SCG oil.

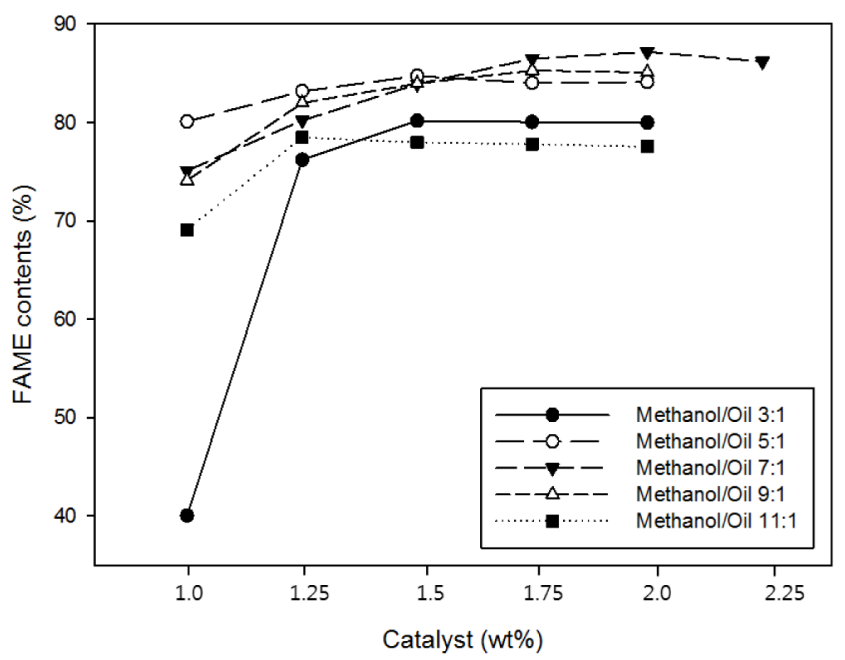

Fig. 1. Effect of catalyst concentration and methanol to oil molar ratio on the FAME content. 


\subsection{Transesterification Using Ultrasound Irradiation}

\subsubsection{Effect of ultrasound amplitude and ultrasound irradiation time}

Fig. 2 shows the FAME content of BD produced by ultrasound-assisted transesterification. Regardless of the ultrasound amplitude tested, the irradiation time of $10 \mathrm{~min}$ was optimal for higher FAME contents. Further increase in reaction time resulted in lower FAME contents. As the FAME content increases, the hydrolysis of ester also increases and finally, dynamic equilibrium is established [17, 36]. In addition, when the reaction is allowed for an extended time, the reverse reaction can limit further transesterification, lowering the product yield and increasing soap formation [37]. The reduced reaction time by ultrasound irradiation can be associated with the ultrasonic cavitation. This provides sufficient energy to activate the transesterification of the SCG oil and increase the reactivity by improving alcohol-oil mixing [38]. With respect to ultrasound amplitude, the FAME content increased in the range of 24.8-99.2 $\mu \mathrm{m}$. A slight decrease in the FAME content was observed at higher amplitude $(117.8 \mu \mathrm{m})$. High ultrasound amplitudes induce the cushioning effect, which reduces the energy available for the activation of the transesterification reaction [18]. In summary, the optimal amplitude and irradiation time were 99.2 $\mu \mathrm{m}$ and $10 \mathrm{~min}$, respectively, and the combination of these parameters produced the highest FAME content of 90.8\%. The FAME content was significantly lower (34.2-41.6\%) with the amplitude of $24.8 \mu \mathrm{m}$.

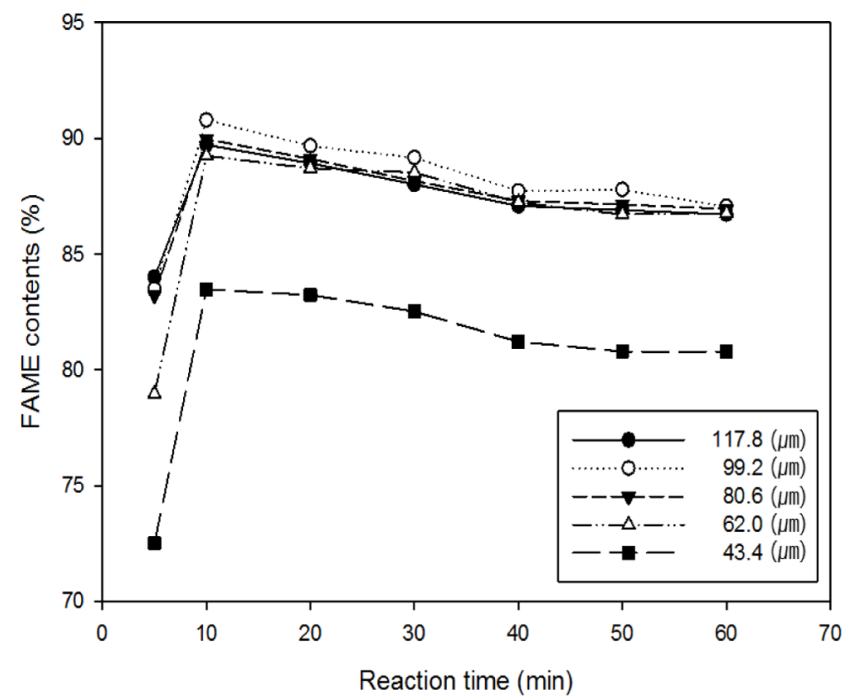

Fig. 2. Effect of ultrasound amplitude and reaction time on the FAME content with methanol to oil molar ratio of 7:1 and catalyst concentration of 1.5 wt.\%.

\subsubsection{Effect of methanol to oil molar ratio and catalyst concen- tration}

Fig. 3 shows the effects of the methanol to oil molar ratio and catalyst concentration on the transesterification of SCG oil at the optimal sonication condition. The highest FAME content was 97.2\% with methanol to oil molar ratio of 7:1 and catalyst concentration of 1.25 wt.\%. The BD yield at this condition was $74 \%$. The FAME content increased as the methanol to oil molar ratio increased from 3:1 to 7:1. Further increase of methanol negatively affected the FAME content. Overload of methanol hinders proper phase separation of ester and water, and methanol can emulsify the reaction mixture, reducing the ester conversion [18, 37]. With respect to catalyst concentration, the FAME content peaked at catalyst concentration of $1.25 \mathrm{wt} . \%$ and at the concentration above that, the FAME content was lower than the maximum. In general, the conversion rate increases with catalyst concentrations; however, an excessive amount of catalyst can react with triglyceride, lowering conversion efficiency due to increased saponification [18, 37, 39].

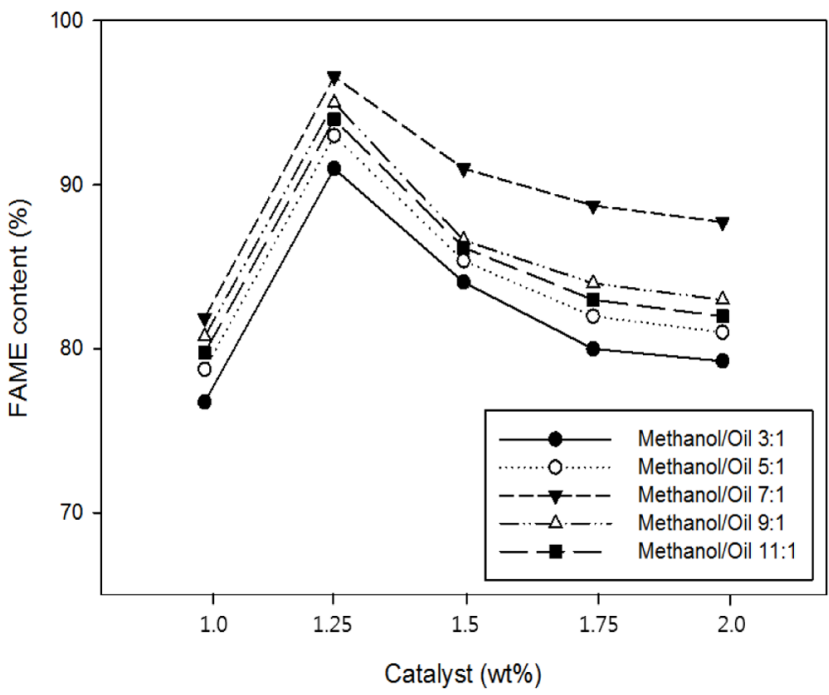

Fig. 3. Effect of molar ratio of methanol to oil and catalyst concentration on FAME contents at ultrasonic amplitude of $99.2 \mu \mathrm{m}$ and ultrasound irradiation time (reaction time) of $10 \mathrm{~min}$.

The FAME content in the BD produced using the optimal ultrasound-irradiation condition was $97.2 \%$ and the BD yield was $74 \%$. In the meanwhile, the highest FAME content in the BD produced using mechanical string was $87.8 \%$ and the BD yield was $56.2 \%$. Compared to mechanical transesterification, ultrasound-assisted transesterification improved the FAME content and BD yield by $9.4 \%$ and $17.8 \%$, respectively. In addition, the reaction time was significantly shortened in ultrasound-assisted transesterification (10 vs. 60 min.) [14]. Together, the reduced amount of catalyst (by $37.5 \%$ ) and reaction time (by $83.3 \%$ ) could improve the economic efficiency of BD production from SCG. In addition, the BD production per hour was $106.8 \%$ higher when ultrasound irradiation was used instead of mechanical stirring. Regarding the FAME content, only BD produced using the ultrasound-assisted process satisfied the standard requirement. The effects of ultrasound irradiation on the FAME content in BDs have been reported in previous studies. Francisco et al. [40] reported that the ultrasound-assisted transesterification of fish waste oil increased the FAME content by $15 \%$ compared to the conventional mechanical stirring. According to Stavarache et al. [39], the ultrasound-assisted transesterification process in the presence of $\mathrm{KOH}$ as a catalyst resulted in a $33 \%$ reduction in reaction time and a $10 \%$ increase in the 
FAME conversion compared to the mechanical stirring process. The ultrasonic cavitation generates energy to increase the interphase between oil and methanol, and consequently transesterification reactivity, allowing for a higher ester conversion in a reduced reaction time [14, 37].

\subsection{Analysis of Energy Consumption}

The energy consumptions as a function of the irradiated ultrasound amplitude are summarized in Table 2. The larger the amplitude, the higher the energy consumption. In the range of the amplitude between 24.8 and $117.8 \mu \mathrm{m}$, the ultrasound energy ranges from 5.28 to $362.9 \mathrm{~kJ}$, and the power consumption from 17.6 to 100.6 W. The energy consumption in the best condition (amplitude 99.2 $\mu \mathrm{m}$ and reaction time $10 \mathrm{~min}$ ) was $51.4 \mathrm{~kJ}$. The amount of energy used in the transesterification reaction was $126 \mathrm{~kJ}$. The amount of energy consumed by ultrasound-assisted transesterification was $59 \%$ lower than that by mechanical stirring. Compared to the ultrasound-assisted transesterification, the mechanical stirring process requires a longer reaction time and continuous heating to keep the reaction temperature constant, which could result in the overall higher energy consumption [41]. Yin et al. [41] reported that the energy consumed in the ultrasound-assisted transesterification of sunflower oil was approximately $42 \%$ lower than that of mechanical stirring. In their study, the reaction time was also reduced by 50\% when ultrasound was used during transesterification. Furthermore, ultrasound-assisted transesterification is reported to improve energy efficiency by approximately $45 \%$ compared to mechanical stirring [42]. As such, the energy requirement of the ultrasound-assisted process is lower than that of the mechanical stirring.

Table 3 shows the amount of energy and time required to produce $1 \mathrm{~L}$ of SCG-derived BD by ultrasound irradiation and mechanical stirring method. The ultrasound irradiation process was $12.5 \%$ lower in electricity consumption and $33.6 \%$ shorter in reaction time. The difference in reaction time can be explained with the ultrasound-induced reaction activation [43, 44]. Moreover, the mechanical stirring method requires hour-long heating, consuming a substantial amount of energy. According to Ji et al. [14], the ultrasound-assisted transesterification process of soybean oil achieved a higher FAME content within a shorter reaction time compared to the stirring method. In addition, the energy consumption for BD production was $250 \mathrm{Wh} / \mathrm{kg}$ for ultrasound and $500 \mathrm{Wh} / \mathrm{Kg}$ for mechanical stirring. The ultrasound-irradiation method consumed half of the energy required by the stirring method. Thanh et al. [45] reported that the FAME content increased from $81 \%$ to $99 \%$ with ultrasound irradiation. The additional benefit included less amounts of methanol and catalyst for transesterification, and reduced reaction time. These results show that the ultrasound-assisted conversion is an efficient method to produce BD in a short time with high energy efficiency [46].

Table 2. Amount of Irradiated Ultrasound Energy in Accordance with Ultrasound Amplitude and Irradiation Time (unit: kJ)

\begin{tabular}{|c|c|c|c|c|c|c|}
\hline \multirow{2}{*}{$\begin{array}{l}\text { Irradiation time } \\
\text { (min) }\end{array}$} & \multicolumn{6}{|c|}{ Ultrasound amplitude $(\mu \mathrm{m})$} \\
\hline & $24.8 \mu \mathrm{m}$ & $43.4 \mu \mathrm{m}$ & $62.0 \mu \mathrm{m}$ & $80.6 \mu \mathrm{m}$ & $99.2 \mu \mathrm{m}$ & $117.8 \mu \mathrm{m}$ \\
\hline 5 & 5.3 & 9.7 & 15.1 & 19.4 & 25.8 & 30.1 \\
\hline 10 & 10.5 & 19.5 & 30.2 & 38.8 & 51.4 & 60.4 \\
\hline 20 & 21.1 & 38.9 & 60.2 & 77.7 & 102.8 & 120.7 \\
\hline 30 & 31.8 & 58.3 & 90.4 & 116.4 & 154.3 & 181.0 \\
\hline 40 & 42.7 & 77.8 & 120.8 & 155.3 & 205.7 & 240.9 \\
\hline 50 & 52.5 & 97.2 & 150.6 & 193.8 & 257.0 & 301.8 \\
\hline 60 & 63.4 & 116.6 & 181.0 & 232.9 & 308.5 & 362.9 \\
\hline
\end{tabular}

Table 3. Energy and Time Consumption in Accordance with Transesterification Methods

\begin{tabular}{|c|c|c|c|}
\hline \multicolumn{2}{|l|}{ Process } & \multirow{2}{*}{$\begin{array}{c}\text { Ultrasound irradiation } \\
119\end{array}$} & \multirow{2}{*}{$\begin{array}{c}\text { Mechanical stirring } \\
62.5\end{array}$} \\
\hline \multirow{3}{*}{ Transesterification } & Power $(\mathrm{W})$ & & \\
\hline & Time (h) & 0.16 & 1 \\
\hline & Energy consumption (Wh) & 19 & 62.5 \\
\hline \multirow{3}{*}{ Washing } & Power (W) & 150 & 150 \\
\hline & Time (h) & 0.5 & 0.5 \\
\hline & Energy consumption (Wh) & 75 & 75 \\
\hline \multirow{3}{*}{ Drying } & Power (W) & 210 & 210 \\
\hline & Time (h) & 1 & 1 \\
\hline & Energy consumption (Wh) & 210 & 210 \\
\hline \multicolumn{2}{|c|}{ Time total (h) } & 1.66 & 2.5 \\
\hline \multicolumn{2}{|c|}{ Energy consumption total (Wh) } & 304 & 347.5 \\
\hline
\end{tabular}




\subsection{Economic Feasibility}

The energy and material costs per $1 \mathrm{~L}$ of BD from SCG are summarized in Table 4. The ultrasound-assisted process was $45 \%$ and $14 \%$ lower in energy and material cost, respectively, compared with the mechanical stirring method. The total cost was reduced by approximately $44 \%$. The cost reduction could be attributed to the reduced amount of catalyst required for transesterification, a higher BD yield, and a shorter reaction time. Stavarache et al. [47] reported that, compared with mechanical stirring, ultrasound-assisted transesterification improved the FAME conversion rate by $18 \%$ and reduced the reaction time and catalyst requirement. According to Singh et al. [48], by replacing mechanical stirring with ultrasound irradiation, the reaction time of the transesterification of microalgae oil could be reduced from $5 \mathrm{~h}$ to $15 \mathrm{~min}$ and the FAME content could be increased from 91 to $98 \%$. According to Sivaramakrishnan et al. [46], for BD production from microalgal oil, the reaction time and energy consumption required were $4 \mathrm{~h}$ and $38.09 \mathrm{~kW}$, respectively, in the ultrasound-assisted process, and $36 \mathrm{~h}$ and 1,028.57 kW, respectively, in the mechanical stirring process. This suggests that the ultrasound-based BD production could be substantially more cost-effective. Overall, compared with the conventional mechanical stirring process, ultrasound-assisted transesterification is a more economically viable approach for BD production, featuring a shorter reaction time, lower energy consumption, and higher product purity.

In this study, BD was produced from untreated SCG using ultrasound-assisted transesterification reaction. In the mechanical stirring process, without pretreatment, the $\mathrm{BD}$ quality standard (FAME content ${ }^{3}$ 96.5\%) could not be met due to the high FFA content in SCG. For this reason, raw materials with high FFA contents require a pretreatment process. To estimate the additional energy and material cost for SCG pretreatment, the SCG samples used for BD production were pretreated with sulfuric acid. The time and amount of energy required for the pretreatment process were $1.3 \mathrm{~h}$ and $0.14 \mathrm{kWh}$, respectively, which were translated into additional energy and material costs of US\$ 0.011/L and US\$ 0.029/L, respectively. According to Y. Zhang et al. [12], the cost for the pretreatment equipment accounts for $46 \%$ of the total equipment cost. When the energy and process time cost resulting from the pretreatment are added up to total process cost, the difference in economic efficiency between the mechanical stirring and the ultrasound-assisted process become more noticeable.

Overall, the ultrasound-assisted process could be an economically viable alternative to the conventional mechanical stirring method for a high-quality industrial BD production. The economic improvements are in part attributed to the direct use of SCG without any pretreatment.

\subsection{Analysis of the Physical and Chemical Properties of SCG Biodiesel}

The physicochemical properties of SCG BD are summarized in Table 5 in comparison with the BD and commercial diesel quality standards. The sulfur content, flash point, ash, water content, and density of SCG BD satisfied both quality standards. The oxidation stability of SCG BD was $6.6 \mathrm{~h}$, higher than the BD standard of $6.0 \mathrm{~h}$, and the cetane number was also higher than the BD standard. The cold filter plugging point (CFPP) of the SCG BD was $-2^{\circ} \mathrm{C}$, which was lower than the $\mathrm{BD}$ standard of $2^{\circ} \mathrm{C}$, but higher than the commercial diesel standard of $-182^{\circ} \mathrm{C}$.

Table 4. Energy Cost and Used Material Cost in Accordance with BD Production Methods (unit: \$)

\begin{tabular}{llcc}
\hline Process & & Ultrasound irradiation & Mechanical stirring \\
\hline \multirow{2}{*}{ Material cost } & SCG & 0.28 & 0.45 \\
& Methanol & 0.03 & 0.05 \\
Energy cost & Potassium hydroxide & 0.07 & 0.19 \\
Total & & 0.024 & 0.028 \\
\hline
\end{tabular}

Table 5. Physicochemical Properties of SCG BD in Comparison with the Quality Standards of BD and Commercial Diesel

\begin{tabular}{|c|c|c|c|c|}
\hline Specification & Unit & BD quality standard & Diesel quality standard & SCG BD \\
\hline Sulfur content & $\mathrm{mg} / \mathrm{kg}$ & $<10$ & $<10$ & 8 \\
\hline Calorific value & $\mathrm{MJ} / \mathrm{kg}$ & - & 45 & 39.58 \\
\hline Flash point & ${ }^{\circ} \mathrm{C}$ & $120<$ & $40<$ & 172 \\
\hline Ash content & $(\mathrm{m} / \mathrm{m}) \%$ & $<0.01$ & $<0.02$ & 0.005 \\
\hline Water content & $(\mathrm{m} / \mathrm{m}) \%$ & $<0.05$ & $<0.02$ & 0.015 \\
\hline Density at $15^{\circ} \mathrm{C}$ & $\mathrm{kg} / \mathrm{m}^{3}$ & $860-900$ & $815-835$ & 892.1 \\
\hline Oxidation stability & $110^{\circ} \mathrm{C}, \mathrm{h}$ & $6<$ & - & 6.6 \\
\hline CFPP & ${ }^{\circ} \mathrm{C}$ & $<0$ & $<-18$ & -2 \\
\hline Cetane number & - & $47<$ & $52<$ & 48 \\
\hline Content of fatty acid methyl ester & Volume \% & $96.5 \leq$ & - & 97.2 \\
\hline
\end{tabular}




\subsection{Analysis of Environmental Effect with SCG BD}

$\mathrm{BD}$ is an environmentally friendly energy source (produced from biomass oils) that emits much less car-bon monoxide (CO), hydrocarbon (HC), and particulate matter (PM) than conventional diesel (CD). According to a previous study, the PM, CO, and HC emission could be reduced by approximately 10,21 , and $11 \%$, respectively, by adding BD to CD up to $20 \%$ [21]. Jaliliantabar et al. [49] compared the soot, $\mathrm{CO}$, and $\mathrm{HC}$ emission from engines running on $\mathrm{CD}$ and SCG BD20 (20\% SCG BD blended with $80 \%$ CD by volume) at various engine loads. They found that soot, $\mathrm{CO}$, and $\mathrm{HC}$ emission were down by $46 \%, 57 \%$, and $77 \%$, respectively, when the engine was fueled with SCG BD20. This could be associated with complete combustion facilitated by oxygenated components and lower sulfur and residual carbon contents in the $\mathrm{BD}$ [50-52]. Moreover, as a carbon-neutral fuel, the natural carbon sequestration reduces $\mathrm{CO}_{2}$ emissions from BD by $50-80 \%$ compared to CD [53-55].

In Korea, the annual SCG production exceeds 120,000 tons (as of 2016). SCG is classified as industrial waste and is incinerated or used for landfill. The cost of SCG disposal is estimated to be approximately US\$ 13 million per year [56, 57]. According to previous report, the disposal cost of SCG can be as much as EUR€ $0.12 / \mathrm{kg}$ [58]. Landfilling and incineration of SCG have an adverse impact on the environment, including soil ecosystem destruction and greenhouse gas emissions [55]. The amount of GHG emissions from waste treatment in Korea (as of 2016) is 16.5 million tons of $\mathrm{CO}_{2} \mathrm{eq}$, which corresponds to $2.4 \%$ of the total greenhouse gas emissions [59]. SCG accounts for approximately $0.6 \%$ of all municipal waste, and the GHG emitted during the disposal is estimated at approximately 99,000 tons of $\mathrm{CO}_{2}$ eq. [57, 59, 60]. A kg SCG $\mathrm{BD}$ has a reduction effect of $2.1 \mathrm{~kg} \mathrm{CO}_{2} \mathrm{eq}$, which means 21 tons of $\mathrm{CO}_{2} \mathrm{eq}$ GHG can be saved by producing 10 tons of $\mathrm{BD}$ from SCG [31]. These analysis results show the environmental and economic benefits of using waste SCG [61].

\section{Conclusions}

In this study, we identified the optimal sonication parameters for the alkali-catalyzed transesterification of SCG oil. The highest FAME content (97.2\%) was achieved at ultrasound amplitude of $99.2 \mu \mathrm{m}$, reaction time of $10 \mathrm{~min}$, methanol to oil molar ratio of 7:1, and $\mathrm{KOH}$ concentration of 1.25 wt.\%. Compared with BD produced by the conventional mechanical stirring method, the FAME content of the SCG oil was increased, and the reaction time was reduced to one-sixth.

Due to the high FFA contents of the SCG oil, the BD produced through mechanical transesterification reaction did not meet the BD quality standard. In contrast, the ultrasound-assisted transesterification was efficient for producing the BD from untreated SCG oil that meets the BD standard. In addition, we found that energy and material cost can be reduced by replacing the mechanical stirring process with the ultrasound-assisted process. In conclusion, SCG-derived BD has substantial economic value with a small environmental footprint and could be a promising alternative to the current CD fuels.

\section{Acknowledgments}

This work was supported by the Korea Institute of Planning and Evaluation for Technology (IPET) in Food, Agriculture, Forestry, and Fisheries through the Agriculture, Food and Rural Affairs Research Center Support Program, funded by the Ministry of Agriculture, Food, and Rural Affairs (MAFRA)(716001-7).

\section{Author Contributions}

Yeong-Su Kim (ph.D. student) conducted the experiments. Duk-Gam Woo (Post-doctoral researcher) as a corresponding author planned the experiments and wrote the manuscript.

Tae-Han Kim (Professor) led the overall research as a corresponding author and helped revised the manuscript.

\section{Nomenclature}

$\begin{array}{ll}\text { AV } & \text { Acid Value } \\ \text { BD } & \text { Bio-Diesel } \\ \text { FAME } & \text { Fatty Acid Methyl Ester } \\ \text { FFA } & \text { Free Fatty Acid } \\ \text { LAME } & \text { Linolenic Acid Methyl Ester } \\ \text { SCG } & \text { Spent Coffee Grounds } \\ \text { KOH } & \text { Potassium hydroxide } \\ \text { NaOH } & \text { Sodium hydroxide } \\ \text { CFPP } & \text { Cold Filter Plugging Point } \\ \text { FID } & \text { Flame Ionization Detector } \\ \text { CD } & \text { Conventional Diesel }\end{array}$

\section{References}

1. Ataya F, Dude MA, Ternan M. Acid-catalyzed transesterification of canola oil to biodiesel under single- and two-phase reaction conditions. Energ. Fuels 2007;21:2450-2459.

2. Thanh LT, Okitsu K, Sadanaga Y, Takenaka N, Maeda Y, Bandow $\mathrm{H}$. Ultrasound-assisted production of biodiesel fuel from vegetable oils in a small scale circulation process. Bioresour. Technol. 2010;101:639-645.

3. International coffee organization. Coffee market report-November 2018. [Internet]. c 2018 [cited 20 December 2018]. Available from: http://www.ico.org/Market-Report-18-19e.asp.

4. Murthy PS, Naidu MM. Sustainable management of coffee industry by-products and value addition- A review. Resour. Conserv. Recycl. 2012;66:45-58.

5. Martinez-Saez N, García AT, Pérez ID, et al. Use of spent coffee grounds as food ingredient in bakery products. Food Chem. 2017;216:114-122.

6. Campos-Vega R, Loarca-Piña G, Vergara-Castañeda HA, DaveOomah B. Spent coffee grounds: A review on current research and future prospects. Trends Food Sci. Technol. 2015;45:24-36. 
7. Tuntiwiwattanapun N, Monono E, Wiesenborn D, Tongcumpou C. In-situ transesterification process for biodiesel production using spent coffee grounds from the instant coffee industry. Ind. Crops Prod. 2017;102:23-31.

8. Al-Hamamre Z, Foerster S, Hartmann F, Kröger M, Kaltschmitt M. Oil extracted from spent coffee grounds as a renewable source for fatty acidmethyl ester manufacturing. Fuel 2012;96:70-76.

9. Canakci M, Gerpen JV. Biodiesel production from oils and fats with high free fatty acids. Trans. ASAE 2001;44:1429-1436.

10. Blinová L, Bartošová A, Sirotiak M. Biodiesel production from spent coffee grounds. Fac. Mater. Sci. Technol. 2017;25:113-121.

11. Zullaikah S, Lai CC, Vali SR, Ju YH. A two-step acid-catalyzed process for the production of biodiesel from rice bran oil. Bioresour. Technol. 2005;96:1889-1896.

12. Zhang Y, Dubé MA, McLean DD, Kates M. Biodiesel production from waste cooking oil: 2. Economic assessment and sensitivity analysis. Bioresour. Technol. 2003;90:229-240.

13. Deng X, Fang Z, Liu Y. Ultrasonic transesterification of Jatropha curcas L. oil to biodiesel by a two-step process. Energ. Convers. Manage. 2010;51:2802-2807.

14. Ji J, Wang J, Li Y, Yu Y, Xu Z. Preparation of biodiesel with the help of ultrasonic and hydrodynamic cavitation. Ultrasonics 2006;44:411-414.

15. Stavarache C, Vinatoru M, Maeda Y. Ultrasonic versus silent methylation of vegetable oils. Ultrason. Sonochem. 2006;13: 401-407.

16. Georgogianni KG, Kontominas MG, Pomonis PJ, Avlonitis D, Gergis V. Conventional and in situ transesterification of sunflower seed oil for the production of biodiesel. Fuel Proc. Technol. 2008;89:503-509.

17. Kumar D, Kumar G, Singh P, Singh CP. Fast, easy ethanolysis of coconut oil for biodiesel production assisted by ultrasonication. Ultrason. Sonochem. 2010;17:555-559.

18. Hingu SM, Gogate PR, Rathod VK. Synthesis of biodiesel from waste cooking oil using sonochemical reactors. Ultrason. Sonochem. 2010;17:827-832.

19. Teixeira LSG, Assis JCR, Mendonc DR, et al. Comparison between conventional and ultrasonic preparation of beef tallow biodiesel. Fuel Proc. Technol. 2009;90:1164-1166.

20. Rocha MVP, de Matos LJBL, de Lima LP, et al. Ultrasound-assisted production of biodiesel and ethanol from spent coffee grounds. Bioresour. Technol. 2014;167:343-348.

21. Liu Y, Tu Q, Knothe G, Lu M. Direct transesterification of spent coffee grounds for biodiesel production. Fuel 2017;199: 157-161.

22. Ejikeme PM, Anyaogu ID, Ejikeme CL, et al. Catalysis in biodiesel production by transesterification processes-An insight. J. Chem. 2010;7:1120-1132.

23. Leung DYC, Wu X, Leung MKH. A review on biodiesel production using catalyzed transesterification. Appl. Energ. 2010;87:1083-1095.

24. Burton R, Fan X. Evaluation of two-step reaction and enzyme catalysis approaches for biodiesel production from spent coffee grounds. Int. J. Green Energ. 2010;7:530-536.

25. Al-Hamamre Z, Foerster S, Hartmann F, Kröger M, Kaltschmitt
M. Oil extracted from spent coffee grounds as a renewable source for fatty acid methyl ester manufacturing. Fuel 2012;96:70-76.

26. Maghami M, Sadrameli SM, Ghobadian B. Production of biodiesel from fishmeal plant waste oil using ultrasonic and conventional methods. Appl. Therm. Eng. 2015;75:575-579.

27. Lee SB, Lee JD, Hong IK. Ultrasonic energy effect on vegetable oil based biodiesel synthetic process. J. Ind. Eng. Chem. 2011;17:138-143.

28. Koh LLA, Chandrapala J, Zisu B, Martin GJO, Kentish SE, Ashokkumar M. A comparison of the effectiveness of sonication, high shear mixing and homogenization on improving the heat stability of whey protein solutions. Food Bioproc. Technol. 2014;7:556-566.

29. Cao X, Zhang M, Mujumdar AS, Zhong Q, Wang Z. Effects of ultrasonic pretreatments on quality, energy consumption and sterilization of barley grass in freeze drying. Ultrason. Sonochem. 2018;40:333-340.

30. Su Y, Zhang M, Zhang W, Liu C, Adhikari B. Ultrasonic microwave-assisted vacuum frying technique as a novel frying method for potato chips at low frying temperature. Food Bioprod. Proc. 2018;108:95-104.

31. Kookos IK. Technoeconomic and environmental assessment of a process for biodiesel production from spent coffee grounds (SCGs). Resour. Conserv. Recycl. 2018;134:156-164.

32. Korea Electric Power Corporation. Power rates system [Internet]. c2019 [cited 30 April]. Available from: http://cyber.kepco. co.kr/ckepco/front/jsp/CY/H/C/CYHCHP00104.jsp?menuCd= FN0204030104.

33. Aristizábal V, García CA, Cardona CA. Integrated production of different types of bioenergy from oil palm through biorefinery concept. Waste Biomass Valor. 2016:7:737-745.

34. Budžaki S, Miljić G, Sundaram S, Tišma M, Hessel V. Cost analysis of enzymatic biodiesel production in small-scaled packed-bed reactors. Appl. Energ. 2018;210:268-278.

35. Gerpen JV. Biodiesel processing and production. Fuel Proc. Technol. 2005;86:1097-1107.

36. Leung DYC, Guo Y. Transesterification of neat and used frying oil: Optimization for biodiesel production. Fuel Proc. Technol. 2006;87:883-890.

37. Eevera T, Rajendran K, Saradha S. Biodiesel production process optimization and characterization to assess the suitability of the product for varied environmental conditions. Renew. Energ. 2009;34:762-765.

38. Kesgin C, Yücel S, Özçimen D, Terzioğlu P, Attar A. Transesterification of hazelnut oil by ultrasonic irradiation. Int. J. Green Energ. 2016;13:328-333.

39. Stavarache C, Vinatoru M, Nishimura R, Maeda Y. Fatty acids methyl esters from vegetable oil by means of ultrasonic energy. Ultrason. Sonochem. 2005;12:367-372.

40. Santos FFP, Malveira JQ, Cruz MGA, Fernandes FAN. Production of biodiesel by ultrasound assisted esterification of Oreochromis niloticus oil. Fuel 2010;89:275-279.

41. Yin X, Ma H, You Q, Wang Z, Chang J. Comparison of four different enhancing methods for preparing biodiesel through transesterification of sunflower oil. Appl. Energ. 2012;91: 320-325. 
42. Gupta AR, Yadav SV, Rathod VK. Enhancement in biodiesel production using waste cooking oil and calcium diglyceroxide as a heterogeneous catalyst in presence of ultrasound. Fuel 2015;158:800-806

43. Fan X, Chen F, Wang X. Ultrasound-assisted synthesis of biodiesel from crude cottonseed oil using response surface methodology. J. Oleo Sci. 2010;59:235-241.

44. Singh AK, Fernando SD, Hernandez R. Base-catalyzed fast transesterification of soybean oil using ultrasonication. Energ. Fuel 2007;21:1161-1164.

45. Thanh LT, Okitsu K, Sadanaga Y, Takenaka N, Maeda Y, Bandow H. A two-step continuous ultrasound assisted production of biodiesel fuel from waste cooking oils: A practical and economical approach to produce high quality biodiesel fuel. Bioresour. Technol. 2010;101:5394-5401.

46. Sivaramakrishnan R, Incharoensakdi A. Microalgae as feedstock for biodiesel production under ultrasound treatment - A review. Bioresour. Technol. 2018;250:877-887.

47. Stavarache C, Vinatoru M, Nishimura R, Maeda Y. Conversion of vegetable oil to biodiesel using ultrasonic irradiation. Chem. Lett. 2003;32:716-717.

48. Singh A, Pal A, Maji S. Biodiesel production from microalgae oil through conventional and ultrasonic methods. Energ. Sour. Part A 2017;39:806-810.

49. Jaliliantabar F, Ghobadian B, Carlucci AP, et al. Comparative evaluation of physical and chemical properties, emission and combustion characteristics of brassica, cardoon and coffee based biodiesels as fuel in a compression-ignition engine. Fuel 2018;222:156-174.

50. Armas O, Yehliu K, Boehman AL. Effect of alternative fuels on exhaust emissions during diesel engine operation with matched combustion phasing. Fuel 2010;89:438-456.

51. Liaquat AM, Masjuki HH, Kalam MA, et al. Effect of coconut biodiesel blended fuels on engine performance and emission characteristics. Procedia Eng. 2013;56:583-590.

52. Shameer PM, Ramesh K. Green technology and performance consequences of an eco-friendly substance on a 4-stroke diesel engine at standard injection timing and compression ratio. $J$. Mech. Sci. Technol. 2017;31:1497-150.

53. Xue J, Grift TE, Hansen AC. Effect of biodiesel on engine performances and emissions. Renew. Sust. Energ. Rev. 2011;15: 1098-1116.

54. Escobar JC, Lora ES, Venturini OJ, Yáñez EE, Castillo EF, Almazan O. Biofuels: Environment, technology and food security. Renew. Sust. Energ. Rev. 2009;13:1275-1287.

55. Park JS, Kim BR, Son JS, Lee JW. Solvo-thermal in situ transesterification of wet spent coffee grounds for the production of biodiesel. Bioresour. Technol. 2018;249:494-500.

56. National raw information center. Disposal costs according to waste type [Internet]. c2019. [cited 10 May]. Available from: http://www.law.go.kr/admRulBylInfoP.do?bylSeq $=1792018 \& a d m R u l S e q=2100000038780 \& a d m F l a g=0 \& d i$ rectYn $=$ Y.

57. Rural Development Administration (RDA). Manufacturing and utilization of spent coffee grounds compost [Internet]. c2019. [cited 10 May]. Available from: http://www.nongsaro.go.kr/portal/contentsFileView.do?ep=F2H5TAYBh19Z9gi0T0N6PqF1j uab8B2M@r/xMBcjs5BtyvGH/qhCuqmdMsUch4d/.

58. Barbero S, Toso D. Systemic design of a productive chain: Reusing coffee waste as an input to agricultural production. Environ. Qual. Manage. 2010;19:67-77.

59. Greenhouse Gas Inventory and Research Center. National greenhouse gas inventory report in 2018. [Internet]. c2019. [cited 10 May]. Available from: http://www.gir.go.kr/home/board/read. do? pagerOffset $=0 \&$ maxPageItems $=10 \&$ maxIndexPages $=10 \&$ searchKey $=\&$ searchValue $=\&$ menuId $=36 \&$ boardId $=43 \&$ boar dMasterId $=2 \&$ boardCategoryId $=$.

60. Korea Resources Recirculation Information System. Status of waste generation and disposal in 2016. [Internet]. c2019. [cited 12 May]. Available from: http://www.kwaste.or.kr/images/sub04/0101/16.pdf.

61. McNutt J, He Q. Spent coffee grounds: A review on current utilization. J. Ind. Eng. Chem. 2019;71:78-88. 